\title{
Adult Diffuse Mixed Cell Lymphoma
}

National Cancer Institute

\section{Source}

National Cancer Institute. Adult Diffuse Mixed Cell Lymphoma. NCI Thesaurus. Code C7871.

A B-or T-cell non-Hodgkin lymphoma composed of a mixed-sized lymphocytic population occurring in adults. 